\title{
The Developmental State Model in Ethiopia: A Path to Economic Prosperity or Political Repression?
}

\section{Semahagn Abebe}

School of Arts \& Sciences, Endicott College

\begin{abstract}
The most significant policy framework that has been shaping the political and economic dynamics in Ethiopia is the doctrine of the developmental state model. The rhetoric is a new form of policy direction that has been advanced by the Government of Ethiopia since the aftermath of the controversial election in 2005. The policy aims at boosting legitimacy of the regime on the ability of the developmental state to deliver roads, schools and exaggerated rates of gross domestic product (GDP) growth. After the adoption of the developmental state model, the political repression against opposition parties, the media and civil society groups has been intensified. The paper explores the implications of the authoritarian developmental policy of the Ethiopian government in deepening political repression in the country.
\end{abstract}

\section{INTRODUCTION}

A new political dispensation began to unfold in Ethiopia since the change of regime in 1991. The Tigreyan People's Liberation Front (TPLF), under its umbrella organization, the Ethiopian People Revolutionary Democratic Front (EPRDF), assumed state power in May 1991. The swift control of state power happened with the blessing of the United States Government in a bid to prevent the kind of chaos that had devastated Liberian and Somalia (Lyons 1996: 122). There were mixed feelings when the new forces entered the capital. On the one hand, there was a huge sense of hope for change, especially among the ethno-regional political forces hoping for an end to what 
they call 'ethnic exploitation', democratization of the Ethiopian state and prospects of economic development.

The revolution was a complete reversal of the centralization stance and sense of unity that had crystallized for decades. The National Conference on Peace and Reconciliation in July 1991 was organized as the foundation for a transitional period after the regime change. However, the conference had excluded many of the political groups from participation (Solomon 1993: 150; Alemante 1992: 205). The conference largely included selected individuals and over 20 political organizations (Lyons 1996: 123). In 1995, EPRF adopted a new constitution that provides for the establishment of a federal democratic state, multi-party democracy and protection of fundamental and democratic and human rights.

The highly-anticipated promises for democratization and protection of human rights were not realized in the last two decades. A close study of the ideological merits and polices of TPLF/EPRDF is essential in assessing the dynamics of impediments of Ethiopia's transition to democracy and functioning of the federal system. Since 1991, the destiny of the country seems to be closely linked to this organization and its ideological ideals. The party is responsible for the adoption of the highly controversial ethnic federal system and the innumerable Marxist inspired policies that have been used to control all political, social and economic institutions in the country. The polices of TPLF/EPRDF have far-reaching consequences in shaping the country's political discourse. The ideological principles perused by the vanguard party are mainly aimed at preserving the hegemony of the party in decades to come. One of the most important rhetoric that has been regulating the political discourse in Ethiopia is the doctrine of the developmental state. The doctrine is a new form of policy that has been advanced by TPLF/EPRDF, particularly since 2006 . The model aims at boosting legitimacy of the regime on the ability of the developmental state to deliver roads, schools and exaggerated rates of gross domestic product (GDP) growth. After the 2005 election fiasco, the regime vigorously emphasized the concept of the developmental state.

In the last few years, the aggressive application of authoritarian developmentalism has had numerous implications for the country's democratization and federalization process. The developmental state rhetoric is now in full swing in light of the huge foreign land-lease deals, exaggerated growth figures, the mega-dam building and the road construction (Abbink 2011: 598). Much of the news pieces and documents released by the state have focused on developmental is- 
sues. Other issues related to democracy, maladministration, economic challenges and other relevant issues have been entirely excluded from the media coverage. In addition to the reports of economic growth released by the Ethiopian government, the World Bank and other international organizations affirmed that the country had scored more than an average of seven per cent annual economic growth in the last eight years. The paper explores the impacts of the developmental state policy of the Ethiopian government on the democratization process and protection of human rights. It particularly addresses the impacts of the application of the developmental state model in the last decade on institutional building, multi-party democracy, development of civil society and freedom of expression.

\section{THE THEORETICAL BACKGROUND \\ OF THE DEVELOPMENTAL STATE MODEL IN ETHIOPIA}

The term 'developmental state' referred to the phenomenon of stateled macroeconomic planning where the state had autonomous political power as well as control over the economy (Caldentey 2008: 27). The model is particularly associated with the leading role played by the government in promoting industrialization in Japan and other Asian countries such as Korea, Malaysia and Singapore (Ibid.: 27). The strategies involved in achieving economic development include 'the active use of subsidies, tariffs, infant industries and other protectionist measures such as distribution of monopoly rights, development of national capacities through research, development, education, training, stimulus to foreign technology acquisition and public - private cooperation practices' (Ibid.: 31 ).

The inherent backdrop to the theory is that neo-liberal ideals do not work unless some degree of economic development is primarily achieved. According to this assumption widespread poverty and the absence of a democratic civic culture render neo-liberalism incompatible with the realities of poor countries. Democratic reform is only to be undertaken after some degree of economic development has been achieved. Countries such as Singapore, South Korea and Malaysia had followed this model before they opened up their systems to a wider democratic political space. For some time, they were largely repressive regimes that focused only on economic development while being less accountable and transparent. It was only after they had reached some degree of economic development that they undertook democratic reforms. 
TPLF/EPRDF seems to be attempting to imitate the developmental state model to bring about economic transformation in Ethiopia. It is believed that TPLF/EPRDF developed the model combining the work of economists such as Mushtaq Khan, Dani Rodrik, Howard Stein, and Joseph Stiglitz on the key role of the state in achieving economic development and the Chinese economic success (Vaughan 2011: 623). Before the doctrine was adopted as state policy in Ethiopia, it first appeared as a scholarly work by the late prime minster. The preliminary draft of Meles Zenawi's change of policy was presented in advance at a development forum organised by the Initiative for Policy Dialogue in 2006. In his draft thesis, African Development: Dead Ends and New Beginnings (2006), the late prime minister indicates that the neo-liberal paradigm is not working in Africa and argues that the best way to achieve development is the paradigm of the developmental state where the state will have strong power and involvement in directing the political economy of the country (Meles 2006: 10). Meles argued that it is difficult to bring about development in the typical time frame of an election term and that there has to be continuity of policy if there is to be sustained and accelerated economic growth. Though many of the South-East Asian countries implemented the developmental state model through restricting democratic rights, Meles argued that it is possible to achieve developmental state ideals without being repressive. He cited the grand coalitions in Japan and in the Scandinavian countries that stayed in power democratically for longer periods.

As the neo-liberal market economy is labelled negatively as rentseeking or anti-democratic, TPLF/EPRDF claim to have resorted to the developmental state as the only means of economic development in the country (Bach 2011: 650). Under the version of the developmental state doctrine developed by Meles Zenawi, the party and the state become the principal investor and decision-maker in economic matters while the private sector only plays an intermediary role between the two actors (Ibid.: 651). Though the monograph presented by the late prime minister claims that it does not represent the policy of the government, the paradigm shift to developmental state implemented in full swing across the country and it has become the official state policy since 2006. The shift of paradigm to developmental state has brought about radical political and economic measures. Not only has the regime undertaken a number of measures that stifle democratic development such as new laws that restrict the operation of civil society groups and the media as well as anti-terrorism law, other funda- 
mental economic measures related to land lease and private sector investment have been undertaken.

In addition to the huge impact the developmental state paradigm has had on the functioning of the federal system, there are different issues to be raised in relation to the relevance of the model and its possibility in bringing about economic transformation in the Ethiopian context. The primary concern about the use of the model in the Ethiopian context is whether lasting economic development can be achieved through a model that rules out the democratization process. Though Meles Zenawi argued that the developmental state model is not necessarily non-democratic, the experience of the countries that implemented the model, as well as the restriction of the political space in the last few years, indicate that the developmental state model in Ethiopia is implemented through repressive means.

The developmental model, which is aimed at bringing about economic development through undermining democratic values is in direct contradiction with the widely-accepted view that the most important tool for economic development is the existence of a democratic system of government as 'democracies not only out-perform dictatorships when it comes to long-term economic growth, but also outdo them in several other important respects... And they produce more equitable societies. Authoritarian regimes, by contrast, ultimately produce economies that are as fragile as their political systems' (Rodrik 2010). As evidence, the proponents of the democratic model argue that the few countries that developed spectacularly during the past 50 years were under democracy rather than under dictatorship (Przeworski 2004: 21). In most cases, not only are authoritarian governments unable to bring about economic development, or even if they bring about some changes, there is no guarantee such economic promises are sustainable and the gains of economic development may be consumed by the high level of corruption due to the absence of an efficient system of transparency and accountability.

According to scholars, the myth of 'stability' of dictatorships is not also a reality, 'because they rule by force, they are highly vulnerable to any visible signs of dissent ... Since in dictatorships policies depend on the will, and sometimes the whim, of a dictator, they exhibit high variances of economic performance. Some generate miracles, some disasters, and many generate both' (Przeworski 2004: 21). Alternatively, scholars recommend turning instead to up-and-coming economic superpower countries like Brazil, India, South Africa, and Turkey, which have already accomplished their democratic transitions 
and are unlikely to regress (Rodrik 2010). These countries achieved economic development without necessarily denying democratic rights.

The Jasmin revolution that ousted the Tunisian president Ben Ali, Egypt's Hosseni Mubarak, Libya's Ghaddafi and other Middle East countries has proved that the authoritarian developmental rhetoric is not sustainable. Though both Ben Ali and Mubarak had brought about significant economic developments through repressive regimes, growing public consciousness of democracy has resulted in the downfall of entrenched regimes. These are indications that the old style of grip on power in the name of achieving economic development does not work in a technologically developed and interlinked world.

When we assess the success of the Asian tigers that brought about difference through the developmental state model, they were more or less unitary states without complicated heterogeneity as is the case in multinational countries such as Ethiopia. In countries such as China, it is not challenging to maintain stability because of the high degree of linguistic homogeneity and cultural unity. Even in the case of China, without democratic transformation, the lack of institutionalized mechanisms for voicing and organizing dissent will eventually produce conflicts that will overwhelm the capacity of the regime to suppress (Rodrik 2010).

In the African or Ethiopian context, a complicated ethnic and religious diversity needs accommodation through political consensus. In such countries, the appropriate political means that need to be undertaken is a democratic system of government. However, this does not mean that there exist the necessary conditions that enable these countries to build a full-fledged democracy. Since a high level of poverty and illiteracy are deeply entrenched in sub-Sahara African countries, a well-developed democratic system is not a short-term objective in these countries. However, the other myth that asserts that repressive regimes are much better in bringing about change is a more disastrous option for Africa. Due to the untold repression, the people suffer in many parts of Africa, conflicts and frequent change of regimes have occurred in the last few decades.

In addition to this, despite the absence of a democratic system in the Asian countries that pursued the developmental state model, these governments had some credibility among the middle class who brought about economic transformation. This is because the developmental state model requires a highly qualified bureaucracy and civil service that discharge its responsibility efficiently. In China, for instance, the government has been able to mobilize elites under nation- 
alist rhetoric by mobilizing the people to reassert China's traditional position of dominance in the world. Due to the strategy of raising Chinese nationalism, when the Chinese government opened up its free market system, millions of Chinese came back to their homeland to invest and work there, displaying a high sense of nationalism.

In the Ethiopian context, the regime in power does not have the support of the middle class, the technocrats as well as among Ethiopians in the Diaspora. Significant proportions of expatriates could not be convinced to come back to their country to help the development endeavours due to the huge political deficit. The commitment of the most educated elite is unlikely to be realized without some degree of political consensus and freedom in the country. In addition to this, the regime has a bad record in terms of crediting pan-Ethiopian nationalism which is also an essential element to bring about consensus in the country on the notion of the developmental state model. The economic policy in the country also lacks the framework needed for achieving the developmental state model. The Ethiopian political and economic environment operates as a centrally planned economic system rather than adhering to the principles of the developmental state paradigm. Rather than helping to create a conducive investment environment for the private sector, the regime continues to rely heavily on partyaffiliated companies and public enterprises to achieve its developmental objectives.

In addition to the absence of the critical factors needed to implement the developmental state model in the Ethiopian context, the international situation that enabled Asian countries to achieve economic prosperity through the developmental state model has been significantly altered. During the time of the Cold War, due to the fact that Western countries were wary of the expansion of communism, they were generous in terms of providing assistance and facilitating investment opportunities in the regions where they had geopolitical interests. The developmental state in these countries could not have brought about the desired result had it not been for the helping hand of Western powers that were determined to stop the expansion of communism. This situation has been seriously changed since the end of the Cold War. Not only the geopolitical interests have greatly lessened but also the economic crisis in many of the Western countries has restricted the lending hands of the West.

The only economic miracle under the so-called developmental state model after the end of the Cold War is China. But as has been indicated earlier, the degree of homogeneity and the cultural harmony 
in the country has enabled the regime to bring about economic development without opening up the political space. In many respects, the case of China is an exception rather than the norm. Due to China's exceptional situation, scholars warn that it is dangerous to draw too many conclusions from such specific instances since they are rare and there is nothing to show other to generate them (Przeworski 2004: 20). In addition to this, despite China's impressive economic achievements, it has become clear that economic development cannot be maintained without democratic reform in the end.

\section{THE IMPACTS OF THE DEVELOPMENTAL STATE POLICY ON DEMOCRATIC INSTITUTIONS AND SEPARATION OF POWERS IN ETHIOPIA}

The highly centralized feature the Ethiopian state contradicts the very fundamentals of a democratic federal system of government. Except in the case of former socialist federations where the central party controlled the activities of regional units, diverse party interests coexist within federations. The complex relationships within the ruling party and its ideology are thus the major source of the centralized and patronage relationships existing between the federal and regional governments. It has been observed in the last two decades that the principle that governs the patron-client relationship between the TPLF/EPRDF, regional members and affiliate parties has severely hampered a genuine democratization process in the country (International Crisis Group 2009: 17; Milkias 2007: 285).

The regional governments do not have any discretion to reject the policy adopted by the federal government or the right to devise their own policy framework. In many cases, the regional councils adopt federal policy decisions even without altering the words in federal policy documents. After the policy decisions at federal and regionnal levels are finalized, each local administration is required to implement the policy. According to studies, kebele local administrations have particularly become a useful method of control and political repression. Since the kebele administrations are controlled by cadres of the governing party, 'the kebele chairman and leaders closely follow the TPLF/EPRDF, rather than being representative voices of the community' (Yilmaz and Venugopal 2018: 12).

The adoption of the developmental state policy has significantly contributed for affecting the intergovernmental relations between the central and regional governments. The doctrine assumes a government-led economic development strategy that leads to total monopoly 
of the entire political and economic system by a single political force. The aggressive application of the model in the last few years has further narrowed down the limited political space by granting unlimited power to the federal government to interfere and control social, economic and political activities in the country. Due to such unprecedented control by the government, much of the economic, social and political activities in the country has forced citizens to be co-opted into the TPLF/EPRDF state and party machinery for jobs or to improve their livelihoods.

In addition to this, the aggressive use of the developmental model rhetoric has suffocated state structures and the intergovernmental relations of the federal system by narrowing down the political space needed for the accommodation of diverse political interests in the country. The recent practices and measures undertaken in relation to ensuring development in the country have been observed in terms of curbing some of the constitutional autonomy of regional governments. In the last five years, the federal government has taken over much of the power of the regions to administer the land through the pretext of delegation of some of their rights to the federal government. At present, the federal government is increasingly controlling agricultural and industrial plots of land in the regions through a dubious process and the land is being distributed to foreign companies by the central government.

The emergence of the developmental state rhetoric in the last few years has also been instrumental in terms of paralyzing the separation of powers principle among the three branches of the state. Primarily, the developmental state doctrine has narrowed down the political space by granting unlimited power to the government to interfere and control social, economic and political activities in the country. In the pretext of executing development projects in health, education and other economic sectors, the government has controlled major economic activities in the country. To eliminate civil society groups and activists that challenge the authoritarian tendencies of the regime, the government has enacted new laws that provide a wider governmental power to crack down dissent. The new laws that have been enacted since 2007 relating to terrorism, land lease, civil society and other measures have increasingly placed the executive branch of the government beyond any control. The parliament is highly dominated by the ruling TPLF/EPRDF while all the other political forces are excluded from the political process. The parliament does not have any control over the overwhelming power of the executive branch of the 
state. In addition to this, the judicial review power of the courts over the government is very limited due to the lack of clarity of the power of the judiciary over interpreting the constitution and lack of independence of the judiciary.

After the adoption of the developmental state, TPLF/EPRDF has practically used the civil service as a party apparatus. The tendency of compromising the competence of the civil service in favour of political loyalty greatly undermines the effectiveness of the civil service. According to a Human Rights Watch study, the civil service has become highly politicized since 2005, 'Civil servants are subject to propaganda meetings ostensibly to learn about government policy, but in reality this is part and parcel of a process of indoctrination and ultimately a request or threat to join the EPRDF' (Human Rights Watch 2010: 28). As a result, TPLF/EPRDF has produced an army of civil servants who are determined to show absolute loyalty to the party rather than to their job prescriptions or to the public at large.

The way the regime attempts to mobilize public support is through requiring absolute loyalty to its policies without leaving any room for maneuvering. According to studies, non-TPLF/EPRDF members or non-supporters are reportedly more likely to be transferred to undesirable posts and to be bypassed for promotions and there is lack of transparency in staffing decisions (United States Department Human Rights Report 2010). Due to ideologically structured government, civil servants and other professionals are recruited in contradiction to the civil service law that provides that the only criterion to fill a vacancy is the qualification of the person. In the last few years, the trend of compromising quality for loyalty has been on the increase in the various government departments. Despite the fact that the regime does not admit the politicization of the civil service, an interview made with civil servants at federal and regional levels revealed that the most important factor in joining the civil service is loyalty to the ideology of the ruling party while qualifications have a secondary importance. Citizens have also increasingly been co-opted into TPLF/EPRDF state and party machinery for jobs or to improve their livelihoods.

\section{THE IMPACT OF THE DEVELOPMENTAL STATE POLICY ON MULTI-PARTY DEMOCRACY IN ETHIOPIA}

Though TPLF/EPRDF is formally committed to a 'stable multi-party democratic system', its decision-making, organizational principles and discourse reflect the Marxist-Leninist philosophy that has guided the TPLF since its foundation in 1975. Political opponents are always 
presented by TPLF/EPRDF as 'anti-people' and 'country's enemies'. The various party documents of TPLF/EPRDF indicate that the key to development is a one-party state. The vision that aimed at maintaining hegemony is manifested in various repressive measures taken against opposition party members that include extra-judicial killings, imprisonment and intimidation. Opposition parties are not allowed to operate in rural areas that are considered to be within the power base of the regime, since rural Ethiopia is entirely controlled by the regime. It is unlikely a strong opposition party could emerge without engaging in political activity in rural areas where 85 per cent of the population are residing.

The repressive mechanism used by TPLF/EPRDF has also enabled it to manipulate the country's resources to the disadvantage of opposition groups. Since the ruling party controls government resources, it uses them for advancing party activities while the opposition parties do not have any means to conduct advocacy work. During elections, the ruling party uses vehicles, machinery and staff from government offices for party activities and uses their power to create obstacles to mobilization by opposition parties (Pausewang, Tronvoll and Aalen 2002: 12). It is clear that elections conducted under such an ideological regime will not meet the standards of liberal democracies (Tronvoll 2009: 460).

Since the adoption of the developmental state policy after the 2005 elections, the repression against oppression party members and supporters highly intensified. Not only most of the leaders of the opposition party were imprisoned but also the political space was highly shrunk since 2006. The 2010 general election was undertaken in the absence of any meaningful political participation of opposition parties and the public. In an election held in a very restrictive political landscape, EPRDF claimed to have won 99.6 per cent of the parliamentary seats in 2010. In May 2015, the regime claimed that it won all the 547 parliamentary seats. At present, TPLF/EPRDF controls almost allpolitical, social and economic life in the country.

\section{THE IMPACT OF THE DEVELOPMENTAL STATE POLICY ON CIVIL SOCIETY ORGANISATIONS IN ETHIOPIA}

Civil Society Organizations (CSOs) have become now the most important institutions to build a vibrant democratic society and create a bridge between the government and the public. Ever since the occurrence of famine in the country in the 1970s, there has been a steady increase in the number of CSOs in the country. There had been also 
some professional and labour associations during the time of Emperor Haile Selassie I. However, the regime change in 1991 led to the creation of significant numbers of professional associations and trade unions. As of 2009, there were 4,700 organizations registered with the federal justice ministry and an estimated 7,000 NGOs are active across the country (International Crisis Group 2009: 20).

Despite the volume in the number of CSOs in the country, the Ethiopian regimes in the past and present encourage only CSOs that engage in activities related to relief and rural development rather than those that engage in advocacy activities. Government officials and accuse the CSOs of being mouthpieces of opposition parties as well as criticizing them for not engaging in major problems within the country such as degradation and poverty (Milkias 2006: 15). Furthermore, CSOs are also accused of working to please foreign donors as well as the government rather than focusing on advocacy for democratic empowerment and the protection of human rights (Milkias 2006: 26).

The increasing numbers of CSOs suddenly came to a halt in 2005 when they received a serious blow in the aftermath of the elections. The government crackdown on CSOs following the 2005 election crisis was largely due to the increasingly assertive role of CSOs immediately before the election. During the election, due to the unprecedented openness allowed by the regime, many CSOs were engaged in voter education campaigns in many parts of the country. This resulted in the registration and high turnout of voters for the election which helped the opposition that was marginalized during past elections to command higher public support compared to the past. TPLF/EPRDF was not happy about the role of CSOs that gave significantly increased support to the opposition parties among the public.

After the adoption of the developmental state policy in 2006, there has been a total monopoly of the whole system by a single political force, while independent voices in the country are silenced. After the election of 2005, TPLF/EPRDF came up with a new law that restricted the role of CSOs in policy advocacy. The official justification provided by the regime for the new law was to make CSOs more accountable and to prevent foreign powers from meddling in the internal affairs of the country. The CSOs law that was enacted in 2009 gives the government broad powers to oversee, sanction and dismantle entities it considers troublesome. The law makes any work that touches on human rights or governance issues illegal if carried out by foreign non-governmental organizations and labels any Ethiopian organization 
that receives more than 10 per cent of its funding from sources outside of Ethiopia as a 'foreign' entity. By enacting such a rule, most local CSOs were prohibited from engaging in advocacy, human rights, democratic governance and conflict resolution activities.

The late Prime Minister Meles Zenawi's perception of civil society groups is that 'NGOs can only lead to a fragile democracy which does not permit alternative paths to develop. Instead, what Africa needs is a "paradigm shift" from neo-liberalism to an agrarian democracy, where the NGOs would have minimal roles' (Alemseged 2009: 180). The late Prime Minister, who was the architect of the TPLF/EPRDF ideology, further asserted that the "proliferation of NGOs and domestic voluntary organizations is a form of pluralistic patronage which can only lead to a fragile democracy' (Alemseged 2009: 180). Such perceptions with respect to CSOs are in line with the inherent ideological conceptions of TPLF/EPRDF that restricts the role and scope of CSOs.

\section{THE IMPACT OF DEVELOPMENTAL STATE POLICY ON THE INDEPENDENCE OF THE MEDIA IN ETHIOPIA}

The mass media are often referred to as the fourth branch of government because of the power they wield and the oversight function they exercise in democracies. In the contemporary dispensation, the significant impact of the media has contributed much in terms of holding government actions accountable and demanding the transparency of the state. The role of the media is particularly irrepressible when the other institutions of government such as the legislature and the judiciary are weak or corrupted to facilitate abuse of power. In the Ethiopian context, when TPLF/EPRDF came to power in 1991, a national charter that recognized freedom of speech was adopted and a law was issued on freedom of the press. Soon after the issuance of the law, different newspapers, magazines and books hit the market. Citizens welcomed the trend since the action taken to open up the sector to independent media was a watershed moment, because it had been unthinkable during the past regimes.

However, the distribution of the private press was limited to Addis Ababa and other major cities compared to the role of the electronic media that is by far the most important means of mass media in rural Ethiopia. Despite the call to open up the electronic media to the private sector from the beginning, it took almost a decade for a law to be enacted that regulates private electronic media to be allowed. To date, the broadcasting proclamation is yet to be fully implemented. Only a few FM private radio stations are permitted to operate in the capital 
city Addis Ababa. Many of those established are allegedly progovernment or shy away from issues they deem unpleasant for the government. Licenses have never been granted to private shortwave radio and television broadcasters that could reach the general public in rural areas. The government provides various justifications for the delays, although the real justification behind this is the threat posed to its grip on power by the free media.

The common accusation directed by the government to the private media is that they were irresponsible and were political activists devoid of neutrality. This accusation may have been partly true in light of the fact that the vocal newspapers received their inspiration from the ideals of the opposition parties. However, the major reason why they were perceived as affiliated to opposition parties seems to have been associated with the substantial violation of human rights in the country and public grievances that motivated them to publish news items critical of the government rather than having a direct attachment to the opposition groups. Such accusations of partisanship are also questionable considering the myth of the notion of independence of the media. As far as the press operates within the limits of the law, whether they function as political activists or supporters of government is largely irrelevant. For instance, how could we justify the independence of The Washington Post or The New York Times? These newspapers are accused of showing partisanship towards either liberal or conservative attitudes. The New York Times is usually viewed as being part of the liberal press, while The Washington Post is viewed as being conservative. The debate on their neutrality will always exist. Such value judgement issues are left to the preference and judgement of the readers rather than to regulation of the law.

Ideals of the developmental state have obviously direct implications a vibrant press. Due to such an ideological sensitivity of the regime and an attitude that considers free media unfriendly to the system, the Ethiopian press has suffered a series of measures undertaken by the government. There have been frequent arrests and trials of editors, reporters and publishers, and the subsequent closure of many publications, often leading to journalists fleeing the country. The critical private media has virtually disappeared following the crackdown on the opposition after the 2005 elections. In addition to this, the Amharic programmes on Voice of America and Deutsche Welle reported that their broadcasts have been intermittently jammed since 2007 . The government has also blocked all political Ethiopian websites that are critical of the government. 
The most disturbing and sweeping law that undermines freedom of the press is the newly enacted Anti-Terrorism Proclamation adopted in 2009. This proclamation in particular provides a broad and ambiguous definition of terrorism that could be used to criminalize nonviolent political dissent. The proclamation provides that any form of support for acts of terrorism entails a serious criminal penalty. Accordingly, whoever publishes or causes the publication of a statement that is likely to be understood by some or all the members of the public as a direct or indirect encouragement or other inducement for them to commit, prepare or instigate an act of terrorism is punishable with rigorous imprisonment of up to 20 years. The proclamation further provides the intelligence agency with the power to intercept communications by the person suspected of terrorism. Admissible evidence in the case of terrorism in court includes hearsay or indirect evidence or any form of evidence whose source is not to be disclosed. The police may also arrest without a court warrant any person whom they reasonably suspect to having committed or to be committing a terrorist act.

All the rules enshrined under this proclamation potentially violate presumption of innocence, freedom of expression and association, right to privacy and the right of peaceful demonstrations of citizens. The fear that the government may apply the legislation to crack down on dissent has also been confirmed when the government levelled different terrorism charges against many politicians, journalists and civil society activists. Given the bad human rights record of the regime, it invoked the provisions of the anti-terrorism law to crack down on the private media. In fact, a number of newspapers have been closed down and threatened by the Anti-Terrorism Law and many journalists have either fled the country or have been charged and sentenced with harsh penalties.

\section{CONCLUSION}

The most significant impediment to the democratization of the Ethiopian polity and protection of human rights is related to the introduction of leftist ideology in the 1970s that has been firmly maintained by the TPLF/EPRDF. The leftist political ideology, including the recently adopted developmental state policy, is premised on absolute control of all political space. It discourages the establishment of independent political and civil society groups, limits civil liberties and freedom and controls the media. Primarily, it is doubtful if this model could work in the Ethiopian context where an ethnic federal system is in place and there are diverse political interests. Due to the fact that Ethiopia has been following an ethnic federal system to accommodate ethnic diver- 
sity, the system could not function properly in the absence of genuine democracy. Since TPLF/EPRDF has adopted a federal system that grants ethnic groups the right to self-determination including secession, arresting ethno-regional demands on the pretext of achieving development has the potential to ignite political instability in the country. The federal system that has been adopted in Ethiopia by its nature functions solely on the basis of consensus and the opening of the political space to various political groups. In addition to this, the developmental state rhetoric that aims at bringing economic development through encircling democracy seems to be out dated since the waves of democracy at the international level have a significant impact on people under repression. Thus, the best possible avenue for Ethiopia's future is the one where economic development and democracy should go hand in hand.

\section{REFERENCES}

Aalen, L. 2008. Institutionalizing the Politics of Ethnicity: Actors, Power and Mobilization in Southern Ethiopia under Ethnic Federalism. PhD. University of Oslo.

Abbink, J. 2011. Ethnic-based Federalism and Ethnicity in Ethiopia: Reassessing the Experiment after 20 Years. Journal of Eastern African Studies 5: 641-663.

Alemseged, A. 2009. Diversity and democracy in Ethiopia. Journal of Eastern Africa Studies 3: 175-201.

Alemante, S. 1992. Ethiopia: Problems and Prospects for Democracy. William \& 30 Mary Bill of Rights Journal 1 (2): 205-26.

Bach, J.-N. 2011. Abyotawi Democracy: Neither Revolutionary nor Democratic, A Critical Review of EPRDF's Conception of Revolutionary Democracy in Post-1991 Ethiopia. Journal of Eastern African Studies 5: 641663.

Caldentey, E. P. 2008. In Search of the Developmental State. International Journal of Political Economy 37: 27-53.

Chanie, P. 2007. Clientelism and Ethiopia's post-1991 Decentralization. The Journal of Modern African Studies 45: 355-384.

Human Rights Watch Report. 2010. One Hundred Ways of Putting Pressure Violations of Freedom of Expression and Association in Ethiopia. Report 153/Africa

International Crisis Group. 2009. Ethiopia: Ethnic Federalism and Its Discontents. Report 153/Africa.

Lyons, T. 1996. Closing the Transition: The May 1995 Elections in Ethiopia. The Journal of Modem African Studies 34: 121-142. 
Meles, Z. 2006. African Development: Dead Ends and New Beginnings (unpublished).

Milkias, P. 2006. The Role of Civil Society in Promoting Democracy and Human Rights in Ethiopia. A paper presented at the Ethiopian Americans Council Conference on Protecting the Democratic Rights of the Ethiopian people: Reflections and Next Steps. Los Angeles, California, on July 2.

Pausewang, S., Tronvoll, K., and Aalen, L. 2002. Democracy Unfulfilled? In Pausewang, S., Tronvoll, K., and Aalen, L. (eds.), Ethiopia Since the Derg: A Decade of Democratic Pretension and Performance. London: ZED BOOKS.

Przeworski, A. 2004. Democracy and Economic Development. In Zewede, B. and Pausewang, S. (eds.), Ethiopia the Challenge of Democracy from Below. Addis Ababa.

Rodrik, D. 2010. The Myth of Authoritarian Growth. URL: http://www.pro ject-syndicate.org/commentary/rodrik46/English.

Solomon, G. 1993. Nationalism and Ethnic Conflict in Ethiopia. In Crawford Young (ed.), The Rising Tide of Cultural Pluralism. University of Wisconsin Press.

Tronvoll, K. 2009. Ambiguous Elections: The Influence of Non-Electoral Politics in Ethiopian Democratization. The Journal of Modern African Studies 47 (3): 449-474.

Vaughan, S. 2011. Revolutionary Democratic State Building: Party, State and People in the EPRDF's Ethiopia. Journal of Eastern African Studies 5 (4): 579-595.

Yilmaz, S., and Venugopal, V. 2008. Local Government Discretion and Accountability in Ethiopia. International studies Program Working Paper 21: 8-38.

United States Human Rights Report. 2010. URL: https://www.state.gov/j/drl/ rls/hrrpt/2010/index.htm. 